\title{
COVID-19 Pandemic: What Considerations Should Be Taken during the Assessment and Management of COPD Exacerbation?
}

\author{
Saminan Saminan ${ }^{1}$, Linda Julisafrida ${ }^{2}$, Muhammad Ridwan $^{3}$, Nurul Fajri ${ }^{4}$ \\ ${ }^{1}$ Department of Physiology, Faculty of Medicine, Universitas Syiah Kuala, Banda Aceh 23111, Indonesia; ${ }^{2}$ Department \\ of Pulmonology and Respiratory Medicine, Faculty of Medicine, Universitas Syiah Kuala, Banda Aceh 23111, Indonesia; \\ ${ }^{3}$ Departement of Cardiology, Medical Faculty, Universitas Syiah Kuala, Banda Aceh 23111, Indonesia; ${ }^{4}$ Departement of Physics \\ Education, Faculty of Education and Teacher Training, Universitas Serambi Mekkah, Banda Aceh 23245, Indonesia
}

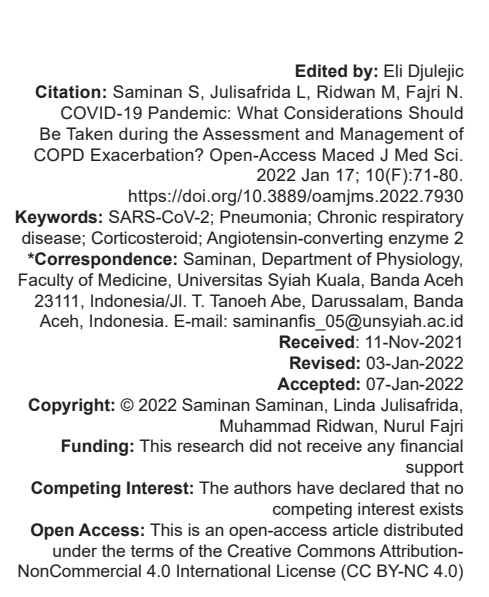

\section{Abstract}

The on-going coronavirus disease 2019 (COVID-19) pandemic could contribute to higher mortality in population with underlying respiratory diseases, including chronic obstructive pulmonary disease (COPD). The aim of this review was to inform readers pertaining to the correlation of COPD exacerbation and severe acute respiratory syndrome-2 (SARS-CoV-2) infection along with considerations that could be taken in the clinical diagnosis and management. The literature search was conducted on Google Scholar, Scopus, and PubMed databases using related terms (such as, but not limited to, "COVID-19," "SARS-CoV-2," "COPD management," "N-acetylcysteine," and "corticosteroids") on November 1-9, 2021. Recent studies suggest that COVID-19 and COPD are correlated through three pathways namely, angiotensin-converting enzyme 2 expression, dysregulation of biological parameters, and occurrence of pneumonia. Early detection of COVID-19 in patients with underlying COPD is difficult because they share similar symptoms, attributed to advanced progression of the infection and subsequently deteriorates lung function. During COPD management, clinicians are expected to take consideration on the effect of systemic corticosteroids if patients develop COVID-19. In conclusion, COVID-19 and COPD and its management are potentially correlated, contributing to the worsening of the disease. There is a need of immediate research to reveal the true correlation between COVID-19 and COPD to improve the management.

\section{Introduction}

Coronavirus disease 2019 (COVID-19) pandemic has impacted multiple sectors not only in caused health problems [1], [2], [3], [4], [5] but also disrupted health-care services [6], environmental management, and economy [7], [8], [9]. Several drugs have been evaluated for COVID-19 [10], [11], [12], [13], [14] and vaccines are also available although the acceptance is difference among countries [15], [16]. In addition, policies also have been adopted in each country [17]. However, the pandemic continues around the globe. The wide spectrum of impact from the COVID-19 was also found in certain group of patients who experience worse impact from the severe acute respiratory syndrome-2 (SARS-CoV-2) infection [18]. In fact, people with underlying comorbidities are more likely to suffer severe course and progression of COVID-19 than those without [19]. A meta-analysis study revealed that respiratory system disease, as one of underlying diseases (others are hypertension and cardiovascular diseases), contribute to the risk factors of severe COVID-19 [20]. Worse COVID-19 symptoms were also reported in patients with chronic respiratory diseases compared to those without [21], [22].

A long-term lung disease, chronic obstructive pulmonary disease (COPD) is one of the non-communicable diseases, which has become a public health problem worldwide [23], [24], [25]. At least in every $4 \mathrm{~min}$, there is one American experiences COPD-related death [26]. Exacerbations in COPD patients could be triggered by viral or bacterial infection (among others) [27]. With the on-going COVID-19 pandemic, hence, patients with underlying COPD could be more susceptible. The following discussions will include the possible and evidenced relationship between COVID-19 and COPD exacerbations. When the relationship exists, modifications on managing patients with COPD are expected. The latest recent work explaining the management for patients with COPD exacerbations and COVID-19 was reported more than a year ago [28]. With more knowledge obtained regarding the nature of SARS-CoV-2 and its correlation with COPD exacerbation, there are many updates that have not been covered in previous literatures. Hence, our work has a novelty in discussing the correlation 
between COPD exacerbations and SARS-CoV-2 infection along with its management using updated research findings.

\section{COPD Exacerbation}

COPD is a common, yet preventable and treatable disease indicated by consistent respiratory symptoms and airflow restriction with abnormalities of airway and/or alveolar [25]. The worsening of this disease within a short duration is called COPD exacerbation, in which the sufferer may require medical care and specific treatment [24], [28], [29]. Based on the pathophysiological features, exacerbations associated with airway inflammation are local and systemic, leading to severe airflow obstruction, imbalance between ventilation perfusion and increased oxygen demand, pulmonary arterial pressure, and cardiac output [30]. Exacerbations could significantly impact COPD patients who are undergoing long-term management, related to patients' health status, quality of life, hospitalization length, and economic burdens [23], [31]. Recurrent exacerbations in COPD patients might result in dramatically increasing morbidity [32, [33]. Exacerbationrelated repeated inflammation could reduce the $1^{\text {st }} \mathrm{s}$ forced expiratory volume (FEV1) and tissue damage concomitant to expiratory airflow obstruction which is followed by $\mathrm{CO}_{2}$ entrapment in lungs [34].

Exacerbations in COPD are caused by various factors, and recent studies are still unable to reveal their exact cause. However, respiratory tract infections by bacteria, viruses, or atypical organisms have been found to play a major role in inducing the exacerbation [27], [35]. The presence of environmental pollution is also among the frequent causes of COPD exacerbations [36], [37]. Amidst the COVID-19 pandemic, concerns on COPD exacerbations are high since around a half of the total cases are caused by viral infections, which are predominated by rhinovirus and respiratory syncytial virus [27], [38]. Viruses could attack airway epithelium increasing its susceptibility against bacterial infections [27], [35]. It is unknown for sure, whether exacerbations are due to mutations of existing bacteria or the acquisition of new bacterial strains because bacteria are also often found in the sputum of clinically stable patients [35].

\section{COVID-19}

SARS-CoV-2 is a novel coronavirus that infects human with a human-to-human transmission through droplets/aerosol, close contact, or fomite routes [39], [40]. The virus has a close relationship with coronaviruses in bats as well as the SARS-CoV-1 virus that is responsible for acute respiratory syndrome (SARS). Penetration to host cells is facilitated by angiotensin-converting enzyme 2 (ACE2) receptor which is expressed in the human airway epithelium and lung parenchyma [41]. The novel virus is more dangerous than SARS-CoV-1 because it has stronger affinity with ACE2 receptor and higher infection rate [42]. Tiny droplets or aerosols, with a diameter ranged from 1 to $2000 \mu \mathrm{m}$, produced from an infected person could act as a transmission medium of the coronavirus [43].

Lungs become the primary targets of SARS-CoV-2 because relatively higher expression of ACE2 is found on the type II alveolar cells (AT2) [44]. However, lung is not the only organ with ACE2, where the protein itself is found in the epithelial cells of myocardial cells, renal tubules, and gastrointestinal cells [45]. Moreover, myocardial infarction is also the cause of ACE2 overexpression which contributes to the development of cardiac injury [46]. Consequently, SARS-CoV-2 infection could cause multiple organ failures [47]. Typical signs patients infected with SARSCoV-2 fever, myalgia, fatigue, nausea, confusion, pains, headaches, dysgeusia, anosmia, diarrhea, and vomiting [48]. Cough, acute respiratory syndrome, and shortness of breath are respiratory symptoms experiences by COVID-19 patients [49]. Impacts of COVID-19 ranged from mild to severe, depending on the underlying condition of the patients. Patients with comorbidities, including COPD exacerbation, could receive worse impact of COVID-19 [50], [51]. Hence, it is important to elucidate the correlation between COPD and COVID-19.

\section{Correlation of COPD Exacerbation and COVID-19}

Although, it has been reported as the most commonly occurring comorbidities in SARS-CoV-2-infected patients, there are only a very few studies drawing correlation between chronic respiratory disease and COVID-19 [52]. Results from several studies suggest that the COVID-19 might worsen the condition of COPD patients along with the increasing risk for exacerbation [53], [54]. Indeed, a study conducted in China revealed significantly lower prevalence of chronic respiratory disease in patients with SARS-CoV-2 infection than that of general population [55]. Yet, studies from the United States and Europe, the prevalence of COPD in COVID-19 patients is at least as high as (if not greater) in the general population [56], [57]. Different results obtained by above studies might be attributed to the underdiagnosis 
and misreporting of COPD among patients with SARSCoV-2 infection [57], [58]. Some other studies agree that worse symptoms could be found if the infected patients have chronic respiratory diseases than patients who do not [21], [22]. Moreover, the stated group of patients experienced increased chance of being admitted to intensive care as well as increased mortality rate [50], [51]. Therefore, it is safe to conclude that there is an association between COVID-19 and COPD exacerbation, where some researches have tried to elucidate the underlying mechanisms as to how the virulence of SARS-CoV-2 plays a role in the exacerbation (Figure 1).

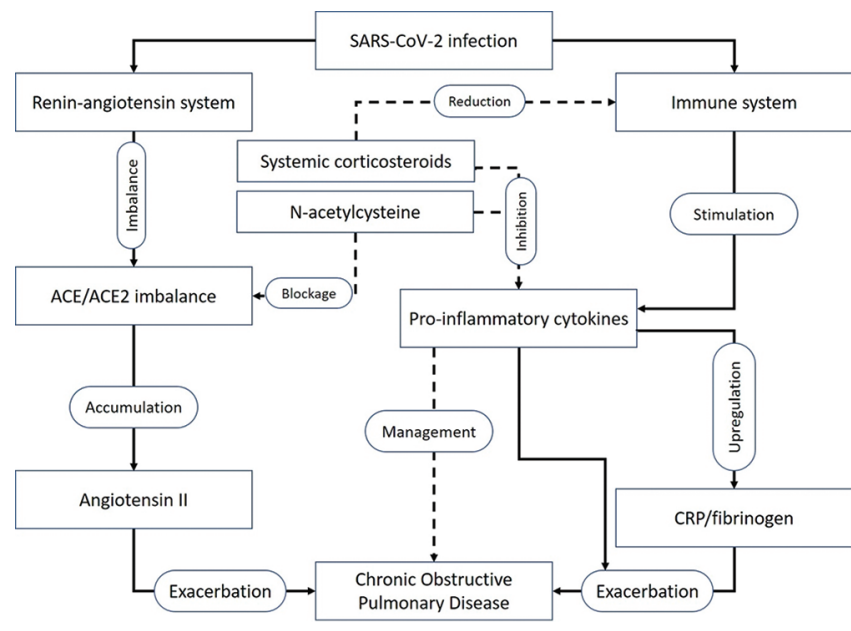

Figure 1: Relationship of SARS-CoV-2 infection with COPD exacerbation. Solid lines describe the role of SARS-CoV-2 infection in exacerbations of COPD. Dashed lines indicate the relationship of drugs given in the management of COPD patients with COVID-19

One of the proposed mechanisms is the involvement of ACE2; a protein expressed on the cell surface in various tissues, facilitating the penetration of SARS-CoV-2 into the host cells [59], [60]. In patients with COPD, this protein is found excessively expressed in the epithelium of the bronchioles [61]. Hence, there are possibilities of COVID-19 worsening through ACE2 overexpression in COPD patients. However, the problem with this proposed mechanism lies on the overexpression of ACE2, where a study in the US disproves the significance of different ACE2 release between COPD and healthy samples [62]. Moreover, ACE2 is downregulated on SARS-CoV-2 infection leading to the elevation of angiotensin (Ang) II plasma that is responsible for the increase of respiratory symptoms [63]. Taken altogether, the dysregulation of ACE2 seems to contribute to the susceptibility to the virus and severity of COVID-19 among patients with COPD which requires further scientific exploration.

Another proposed mechanism of the COPD exacerbation during SARS-CoV-2 infection could be based on the dysregulation of biological parameters including tumor necrosis factor-alpha (TNF- $\alpha$ ), interleukin (IL)-6, C-reactive protein (CRP), lactate dehydrogenase, amyloid A protein, D-dimers, the ratio of neutrophils/lymphocytes, and cardiac troponin [64], [65]. The alteration of the stated parameters may not be dependent on the chronic respiratory disease [66], but the consequences received by the patients with COPD could be different in comparison to those without. For example, increase on TNF- $\alpha$ level during COVID-19 might contribute to the development of COPD exacerbation due to its role in bronchial hyperreactivity [67]. It is also known to be associated with a low maximal expiratory volume per second in patients suffering from COPD [68], which could possibly lead to the exacerbation when the COVID-19 occur.

Notably, the increased level of IL-6 correspond to SARS-CoV-2 infection could be linked to the degradation of lung function [69]. Its increased level has also been linked with higher mortality rate among patients with COPD [70]. IL-6 is also responsible for the upregulation of CRP and fibrinogen [71], in which these molecules were significantly increased in COPD patients [72]. In this case, COPD patients might experience more exacerbations and higher mortality rate [73].

Finally, pneumonia caused by COVID-19 could be proposed as the mechanism of viral infection-induced exacerbation in COPD patients. On the one hand, pneumonia is frequently present in COVID-19 patients, symptomatic or asymptomatic, observed during the advanced progression [74]. On the other hand, pneumonia significantly contributes to longer hospitalization of patients with COPD along with their need for artificial respiration [75]. This is also concerning for COPD patients because the use of inhaled corticosteroids (ICS) could lead to the increasing risk of pneumonia [76].

\section{Symptoms and Clinical Features of Patients with COPD Exacerbation and COVID-19}

COPD patients might not aware of the SARS-CoV-2 infection, especially during its early stage that is only present with mild symptoms. Nonetheless, lung function degradation could occur immediately on the progression into the next stage. Based on a study in the United Kingdom, COVID-19 symptoms among the COPD patients, other than the cough and breathlessness occupying $60 \%$ of the population, included diarrhea, vomiting, fatigue, nausea, confusion, pains, muscle aches, headaches, dysgeusia, and anosmia [48]. It is challenging in COPD patients to early detect the infection as they could have shown the same symptom before the infection. A preliminary observation, as of April 2020, 
suggested that COPD patients were less likely to be tested for COVID-19 even when the mild COVID-19 symptoms had already been observed [77]. Hence, it is recommended to suspect the COPD patients for COVID-19 who have symptoms of an exacerbation, along with gastrointestinal, fever, dysgeusia, or anosmia complaints.

It is important to note that false-negative results for COVID-19 in RT-PCR tests have been found after confirmed using computed tomographic (CT), for which positive results were found later after serial testing [78]. Hence, patients with COPD presenting with fever, respiratory symptoms, or other COVID-19related symptoms should undergo a series of tests for infection possibility (Figure 2). Clinicians should also keep in mind on the presence of coinfection by other pathogens [79]. Recurrence of COVID-19 symptoms is more likely in patients with underlying diseases or undergoing immunosuppressive therapies [80]. It implies the importance of repeat testing on the patients who have been recovered from COVID-19.

Regarding the use of chest radiography for COVID-19 diagnosis, it should be noted that its use on during early stage of infection is not reliable [81]. However, patients with moderate-to-severe COVID-19 symptoms could be indicated by abnormalities under chest radiography, where bilateral pneumonia is found in the most cases [82]. In asymptomatic COVID-19 cases, occurrence of pneumonia could be indicated by CT screening [83]. COVID-19 patients who have COPD tend to have higher local patchy shadowing, ground-glass opacities, and interstitial abnormalities on CT images than those who do not [84]. Pulmonary manifestations from SARS-CoV-2 infection might also be observed using point-of-care lung ultrasound [85].

Countermeasures for COVID-19 transmission risk during the diagnosis or treatment should be considered by either patients or clinicians. Face masks are useful in preventing the transmission of COVID-19 through droplets or aerosols [86]. The use of any face masks would not affect ventilation, even in patients with severely limited airflow [87]. Bronchoscopy on patients with COVID-19 positive should be postponed until the negative results obtained, where in emergency cases, a disposable bronchoscope is recommended [88]. SARSCoV-2 transmission could occur when spirometry and pulmonary function tests were performed. Instead, peak expiratory flow accompanied by validated patient questionnaires could be performed for routine assessment of COPD patients. Indeed, the assessment could not replace spirometry, as the results from the assessment were not correlated with that of spirometry, leading to inability distinguishing obstructive and restrictive lung function disorders [89]. In such cases, remote diagnosis using personal electronic portable spirometer could be employed [90].

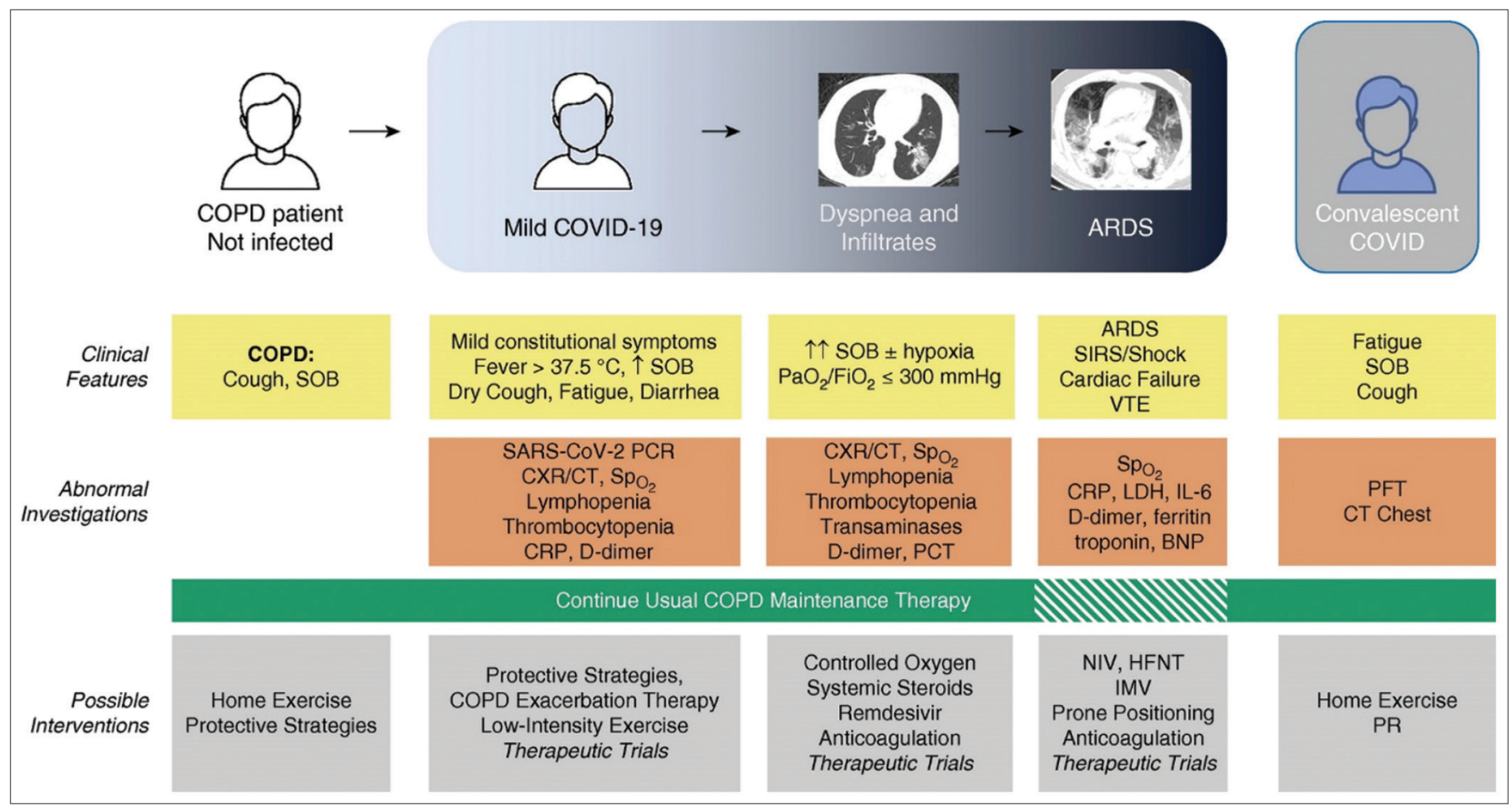

Figure 2: Clinical features and abnormal investigations shared among COPD patients infected with SARS-CoV-2, along with possible interventions. COVID-19=coronavirus disease; $C O P D=$ chronic obstructive pulmonary disease; $S O B=$ shortness of breath; $A R D S=a c u t e$ respiratory distress syndrome; SIRS = systemic inflammatory response syndrome; $V T E=$ venous thromboembolism; CXR $=$ chest radiograph; $C T=$ computed tomography; $\mathrm{SpO}_{2}=$ peripheral oxygen saturation; $C R P=C$-reactive protein; $L D H=$ lactate dehydrogenase; $P C T=$ procalcitonin; $B N P=$ brain natriuretic peptide; $P F T=$ pulmonary function tests; $N I V=$ non-invasive ventilation; $H F N T=$ high-flow nasal therapy; IMV=invasive mechanical ventilation; $P R=$ pulmonary rehabilitation; reproduced under the terms of Creative Commons Attribution Non-Commercial No Derivatives License 4.0 citing [28] 


\section{Management of COPD Exacerbations during COVID-19}

There is no particular different treatment for COPD exacerbation during COPID-19 pandemic. Severity oftheunderlying COPDexacerbationdetermines the type of treatment given to the patients. In fact, there are more than $80 \%$ of cases of exacerbation which could be managed on the patient without hospitalization, accompanied by pharmacological therapy such as bronchodilators, corticosteroids, and antibiotics [91]. In mild and non-infectious exacerbations, patients could be treated at home with a maintenance dosage of bronchodilators [92]. The bronchodilators might include short-acting beta-2-agonists, where combination with short-acting anticholinergics could be given when required [93]. Moderate level of exacerbations requires increased dosage of bronchodilators along with 5 days dosage oral corticosteroids [94].

Along with bronchodilators, corticosteroids are the mainstay of COPD exacerbation management [28]. Employing systemic corticosteroids could improve the recovery time, oxygenation, as well as pulmonary function and reduce the risk of early relapse, treatment failure, and hospitalization duration [95], [96]. During the primary care, $30 \mathrm{mg}$ prednisolone should be given for 7 days [91], where its administration through oral route has been found as effective as the intravenous route [97]. Nonetheless, as also supported by the World Health Organization, a published review suggested to avoid the use of systemic corticosteroids for patients with mild-to-moderate COVID-19 [98]. Either inhaled or oral corticosteroids use in COPD treatment is suggested to be restricted for no longer than 3 months since it could lead to possible adrenal insufficiency [99]. Indeed, several studies show the protective effect of systemic corticosteroids for critically ill patients with ARDS or septic shock (where cytokine storm occurs) [100], [101]. Unfortunately, a study in the UK already reported the insignificance of the protective effect of inhaled corticosteroids toward COVID-19-related mortality [102].

If the exacerbations are caused by bacterial or viral infection, antibiotics treatment might be recommended [29]. Nonetheless, antibiotics for COPD exacerbation management restricted and should only be given when patients possess at least two of the three cardinal symptoms (elevated sputum volume, sputum purulence, and dyspnea) [28], [103]. Patients undergoing mechanical ventilation might also require antibiotics [28]. Preferability of antibiotics use in COPD exacerbations should be considered during the pandemic because of the increased bacterial coinfection prevalence in severe COVID-19 [104]. Moreover, patients with COPD and SARS-CoV-2 infection have been reported to be more susceptible against bacterial or fungal coinfections [84]. Indeed, in mild COVID-19 cases, the bacterial coinfection is not common [105]. Hence, according to the World Health Organization guidelines, patients with mild COVID-19 should only receive broad-spectrum antibiotics when clinical suspicion of bacterial infection is present [106].

Administration of mucolytics and antiinflammatory agents, including the most common $\mathrm{N}$-acetylcysteine (NAC), is also a part of COPD exacerbation management [107]. Mucus hypersecretion has been recognized as a sign of illness exacerbation along with infiltration of inflammatory cells [108], [109]. Furthermore, mucolytics in COPD exacerbation management may disrupt intramolecular interactions of the mucous gel. Once the mucus and remaining sputum are cleared, it allows the accessibility of inhaled drugs to peripheral airways [107]. In particular, NAC has been reported to improve the quality of life of patients with underlying COPD exacerbation [110]. Based on a meta-analysis, NAC is consistently proven to reduce the occurrence of COPD exacerbations with low adverse side effect [111]. Decrease on oxidative biomarkers and improvement on oxidative stress balance on the administration of NAC were observed in COPD patients [110]. Moreover, anti-inflammatory and antioxidant effects from NAC are not only beneficial for COPD patients [112] but also for COVID-19 patients [113]. As a thiol donor, NAC is also a blocker for pulmonary ACE2 reducing the penetrating ability of SARS-CoV-2 into host cells [113], [114].

\section{Conclusion}

Impacts of COVID-19 could be experienced worse, along with higher probability of being admitted to intensive care and mortality rate, in patients with underlying COPD than those without. Susceptibility to COVID-19 is increased by the alteration of ACE2 expression in COPD patients, though it still requires further investigation. Exacerbations of COPD could be triggered or worsened by COVID-19 because of the dysregulation of biological parameters. Pneumonia, commonly occur in severe SARS-CoV-2 infection, is also a triggering factor for COPD exacerbation contributing to more days of hospitalization. Despite its difficulty, early detection of SARS-CoV-2 in patients with underlying COPD is mandatory to prevent further pulmonary function deterioration.

At present, main treatment of COPD exacerbation during COVID-19 pandemic has no significant change. When COPD patients do not develop COVID-19, they could be treated at home along with protective strategies. In general, the management of COPD exacerbations includes therapies with bronchodilators, corticosteroids, and antibiotics. In the presence of SARS-CoV-2 infection, systemic corticosteroids should be carefully prescribed 
because of possible adrenal insufficiency, leading to higher susceptibility against COVID-19. Moreover, inhaled corticosteroids potentially contribute to the increasing risk of pneumonia. It is recommended to administer systemic corticosteroids by considering the severity of the COVID-19. In addition, antibiotics are recommended when patients develop COVID-19 to prevent bacterial coinfection. Management of COPD exacerbation through the administration of NAC is potential for treating COVID-19 which requires further investigation. More changes in the management of COPD exacerbation in patient with COVID-19 are expected in the future as more studies will unveil the correlation of both diseases.

\section{References}

1. Fajar JK, Ilmawan M, Mamada S, Mutiawati E, Husnah M, Yusuf $\mathrm{H}$, et al. Global prevalence of persistent neuromuscular symptoms and the possible pathomechanisms in COVID-19 recovered individuals: A systematic review and meta-analysis. Narra J. 2021;1:e48. https://doi.org/10.52225/narra.v1i3.48

2. Bintari DC, Sudibyo DA, Karimah A. Correlation between depression level and headache severity: A study among medical students during the COVID-19 pandemic. Narra J. 2021;1:e64. https://doi.org/10.52225/narra.v1i3.64

3. Fahriani M, IImawan M, Fajar JK, Maliga HA, Frediansyah A, Masyeni $\mathrm{S}$, et al. Persistence of long COVID symptoms in COVID-19 survivors worldwide and its potential pathogenesis-a systematic review and meta-analysis. Narra J. 2021;1:e36. https://doi.org/10.52225/narraj.v1i2.36

4. Mutiawati E, Syahrul S, Fahriani M, Fajar JK, Mamada SS, Maliga HA, et al. Global prevalence and pathogenesis of headache in COVID-19: A systematic review and meta-analysis. F1000Research 2021;9:1316. https://doi.org/10.12688/ f1000research. 27334.2 PMid:33953911

5. Sarengat R, Islam MS, Ardhi MS. Correlation of neutrophil-tolymphocyte ratio and clinical outcome of acute thrombotic stroke in patients with COVID-19. Narra J. 2021;1:e50. https://doi. org/10.52225/narra.v1i3.50

6. Fahriani M, Anwar S, Yufika A, Bakhtiar B, Wardani E, Winardi W, et al. Disruption of childhood vaccination during the COVID19 pandemic in Indonesia. Narra J. 2021;1:e7. https://doi. org/10.52225/narraj.v1i1.7

7. Wagner AL, Rajamoorthy $\mathrm{Y}$, Taib NM. Impact of economic disruptions and disease experiences on COVID-19 vaccination uptake in Asia: A study in Malaysia. Narra J. 2021;1:e42. https:// doi.org/10.52225/narraj.v1i2.42

8. Dhama K, Patel SK, Kumar R, Masand R, Rana J, Yatoo MI, et al. The role of disinfectants and sanitizers during COVID-19 pandemic: Advantages and deleterious effects on humans and the environment. Environ Sci Pollut Res Int. 2021;28(26):34211-28. https://doi.org/10.1007/s11356-021-14429-w

PMid:33991301

9. Mustafa SK, Ahmad MA, Baranova V, Deineko Z, Lyashenko V, Oyouni A. Using wavelet analysis to assess the impact of COVID-19 on changes in the price of basic energy resources. Int J Emerg Trends Eng Res. 2020;8:2907-12.

10. Rabaan AA, Al-Ahmed SH, Sah R, Al-Tawfiq JA, Al-Qaaneh AM, Al-Jamea $\mathrm{LH}$, et al. Recent advances in vaccine and immunotherapy for COVID-19. Hum Vaccin Immunother. 2020;16(12):3011-22. https://doi.org/10.1080/21645515.2020.1 825896

\section{PMid:33156739}

11. Frediansyah A, Tiwari R, Sharun K, Dhama K, Harapan H. Antivirals for COVID-19: A critical review. Clin Epidemiol Glob Health. 2021;9:90-8. https://doi.org/10.1016/j.cegh.2020.07.006 PMid:33521390

12. Dhama K, Natesan S, Yatoo MI, Patel SK, Tiwari R, Saxena SK, et al. Plant-based vaccines and antibodies to combat COVID-19: Current status and prospects. Hum Vaccin Immunother. 2020;16(12):2913-20. https://doi.org/10.1080/21645515.2020.1 842034

PMid:33270484

13. Sharun K, Tiwari R, Yatoo Ml, Patel SK, Natesan S, Dhama J, et al. Antibody-based immunotherapeutics and use of convalescent plasma to counter COVID-19: Advances and prospects. Expert Opin Biol Ther. 2020;20(9):1033-46. https:// doi.org/10.1080/14712598.2020.1796963 PMid:32744917

14. Mustafa SK, Aljohani MM, Alomrani NA. COVID-19 and immune function-"a significant" zinc. Oriental J Chem. 2020;36:1026-36.

15. Rosiello DF, Ferreto LE, Aburto JT, Rojas JE, Enitan SS, Yomi AR, et al. Acceptance of COVID-19 vaccination at different hypothetical efficacy and safety levels in ten countries in Asia, Africa, and South America. Narra J. 2021;1:e55.

16. Hassan W, Kazmi SK, Tahir MJ, Ullah I, Royan HA, Fahriani M, et al. Global acceptance and hesitancy of COVID-19 vaccination: A narrative review. Narra J. 2021;1:e57.

17. Telles CR, Roy A, Ajmal MR, Mustafa SK, Ahmad MA, De La Serna JM, et al. The impact of COVID-19 management policies tailored to airborne SARS-CoV-2 transmission: Policy analysis. JMIR Public Health Surveill. 2021;7(4):e20699. https://doi. org/10.2196/20699

PMid:33729168

18. Bastola A, Sah R, Rajbhandari SK, Jha R, Fathah Z, Chalise BS, et al. SARS-CoV-2 and Orientia tsutsugamushi co-infection in a young teen, Nepal: Significant burden in limited-resource countries in Asia? Narra J. 2021;1:e34. https://doi.org/10.52225/ narraj.v1i2.34

19. Sanyaolu A, Okorie C, Marinkovic A, Patidar R, Younis K, Desai $\mathrm{P}$, et al. Comorbidity and its impact on patients with COVID19. SN Compr Clin Med. 2020;2(8):1069-76. https://doi. org/10.1007/s42399-020-00363-4

PMid:32838147

20. Yang J, Zheng Y, Gou X, Pu K, Chen Z, Guo Q, et al. Prevalence of comorbidities and its effects in patients infected with SARSCoV-2: A systematic review and meta-analysis. Int J Infect Dis 2020;94:91-5. https://doi.org/10.1016/j.ijid.2020.03.017 PMid:32173574

21. Fan Z, Chen L, Li J, Cheng X, Yang J, Tian C, et al. Clinical features of COVID-19-related liver functional abnormality. Clin Gastroenterol Hepatol. 2020;18(7):1561-6. https://doi. org/10.1016/j.cgh.2020.04.002 PMid:32283325

22. Wang B, Li R, Lu Z, Huang Y. Does comorbidity increase the risk of patients with COVID-19: Evidence from meta-analysis. Aging (Albany NY). 2020;12(7):6049-57. https://doi.org/10.18632/ aging. 103000

PMid:32267833

23. Miravitlles M, Ribera A. Understanding the impact of symptoms on the burden of COPD. Respir Res. 2017;18(1):67. https://doi. org/10.1186/s12931-017-0548-3

PMid:28431503

24. Hanania NA, Sharafkhaneh A. COPD: A Guide to Diagnosis and 
Clinical Management. New Jersey, USA: Humana Press; 2011.

25. Mirza S, Clay RD, Koslow MA, Scanlon PD. COPD guidelines: A review of the 2018 GOLD report. Mayo Clin Proc. 2018;93(10):1488-502. https://doi.org/10.1016/j. mayocp.2018.05.026

PMid:30286833

26. Prasetyowati H, Dhewantara PW, Hendri J, Astuti EP, Gelaw YA, Harapan $\mathrm{H}$, et al. Geographical heterogeneity and socioecological risk profiles of dengue in Jakarta, Indonesia. Geospat Health. 2021;16(1):183-93. https://doi.org/10.4081/gh.2021.948 PMid:33733650

27. Linden D, Guo-Parke H, Coyle PV, Fairley D, McAuley DF, Taggart CC, et al. Respiratory viral infection: A potential "missing link" in the pathogenesis of COPD. Eur Respir Rev. 2019;28(151):180063. https://doi. org/10.1183/16000617.0063-2018

PMid:30872396

28. Halpin DM, Criner GJ, Papi A, Singh D, Anzueto A, Martinez FJ, et al. Global initiative for the diagnosis, management, and prevention of chronic obstructive lung disease. The 2020 GOLD science committee report on COVID-19 and chronic obstructive pulmonary disease. Am J Respir Crit Care Med. 2021;203(1):24-36. https://doi.org/10.1164/ rccm.202009-3533SO PMid:33146552

29. Rabe KF, Hurd S, Anzueto A, Barnes PJ, Buist SA, Calverley $\mathrm{P}$, et al. Global strategy for the diagnosis, management, and prevention of chronic obstructive pulmonary disease: GOLD executive summary. Am J Respir Crit Care Med. 2007;176(6):532-55. https://doi.org/10.1164/ rccm.200703-456SO

PMid: 17507545

30. Stolz D, Papakonstantinou E, Grize L, Schilter D, Strobel W, et al. Time-course of upper respiratory tract viral infection and COPD exacerbation. Eur Respir J. 2019;54(4):1900407. https:// doi.org/10.1183/13993003.00407-2019

PMid:31391222

31. Iheanacho I, Zhang S, King D, Rizzo M, Ismaila AS. Economic burden of chronic obstructive pulmonary disease (COPD): A systematic literature review. Int J Chron Obstruct Pulmon Dis. 2020;15:439-60. https://doi.org/10.2147/COPD.S234942 PMid:32161455

32. Rothnie KJ, Mullerova H, Smeeth L, Quint JK. Natural history of chronic obstructive pulmonary disease exacerbations in a general practice-based population with chronic obstructive pulmonary disease. Am J Respir Crit Care Med. 2018;198(4):464-71. https://doi.org/10.1164/ rccm.201710-20290C

PMid:29474094

33. Mullerova H, Maselli DJ, Locantore N, Vestbo J, Hurst JR, Hurst JA, et al. Hospitalized exacerbations of COPD: Risk factors and outcomes in the ECLIPSE cohort. Chest. 2015;147(4):999-1007. https://doi.org/10.1378/chest.14-0655 PMid:25356881

34. Santos S, Marin A, Serra-Batlles J, de la Rosa D, Solanes I, et al. Treatment of patients with COPD and recurrent exacerbations: The role of infection and inflammation. Int $\mathrm{J}$ Chron Obstruct Pulmon Dis. 2016;11:515-25. https://doi.org/10.2147/COPD. S98333

PMid:27042040

35. Wang $\mathrm{H}$, Anthony $\mathrm{D}$, Selemidis $\mathrm{S}$, Vlahos R, Bozinovski $\mathrm{S}$. Resolving viral-induced secondary bacterial infection in COPD: A concise review. Front Immunol. 2018;9:2345. https://doi. org/10.3389/fimmu.2018.02345

PMid:30459754
36. Heinrich J, Schikowski T. COPD patients as vulnerable subpopulation for exposure to ambient air pollution. Curr Environ Health Rep. 2018;5(1):70-6. https://doi.org/10.1007/ s40572-018-0178-z

PMid:29383658

37. Sun XW, Chen PL, Ren L, Lin YN, Zhou JP, Ni L, et al. The cumulative effect of air pollutants on the acute exacerbation of COPD in Shanghai, China. Sci Total Environ. 2018;622623:875-81. https://doi.org/10.1016/j.scitotenv.2017.12.042 PMid:29227938

38. Liu D, Chen Q, Zhu H, Gong L, Huang Y, Li S, et al. Association of respiratory syncytial virus toll-like receptor 3-mediated immune response with COPD exacerbation frequency. Inflammation. 2018;41(2):654-66. https://doi.org/10.1007/s10753-017-0720-4 PMid:29264743

39. Transmission of SARS-CoV-2: Implications for Infection Prevention Precautions; 2021. Available from: https://www. who.int/news-room/commentaries/detail/transmission-of-sarscov-2-implications-for-infection-prevention-precautions [Last accessed on $2021 \mathrm{Feb} 14]$.

40. van Doremalen N, Bushmaker T, Morris DH, Holbrook MG, Gamble A, Brandi N, et al. Aerosol and surface stability of SARS-CoV-2 as compared with SARS-CoV-1. N Engl J Med. 2020;382(16):1564-7. https://doi.org/10.1056/NEJMc2004973 PMid:32182409

41. Giron CC, Laaksonen A, da Silva FL. On the interactions of the receptor-binding domain of SARS-CoV-1 and SARS-CoV-2 spike proteins with monoclonal antibodies and the receptor ACE2. Virus Res. 2020;285:198021. https://doi.org/10.1016/j. virusres.2020.198021 PMid:32416259

42. Wang $D$, Zhou $M$, Nie X, Qiu W, Yang M, Wang X, et al. Epidemiological characteristics and transmission model of Corona Virus disease 2019 in China. J Infect. 2020;80:e25-7. https://doi.org/10.1016/j.jinf.2020.03.008

PMid:32171870

43. Shafaghi AH, Talabazar FR, Koşar A, Ghorbani M. On the effect of the respiratory droplet generation condition on COVID-19 transmission. Fluids. 2020;5(3):113. https://doi.org/10.3390/ fluids5030113

44. Zhou P, Yang XL, Wang XG, Hu B, Zhang L, Zhang W, et al. A pneumonia outbreak associated with a new coronavirus of probable bat origin. Nature. 2020;579:270-3. https://doi. org/10.1038/s41586-020-2012-7

PMid:32015507

45. Donoghue M, Hsieh F, Baronas E, Godbout K, Gosselin M, Stagliano $\mathrm{N}$, et al. A novel angiotensin-converting enzymerelated carboxypeptidase (ACE2) converts angiotensin I to angiotensin 1-9. Circ Res. 2000;87()5:E1-9. https://doi. org/10.1161/01.res.87.5.e1

PMid:10969042

46. Burrell LM, Risvanis J, Kubota E, Dean RG, MacDonald PS, Lu S, et al. Myocardial infarction increases ACE2 expression in rat and humans. Eur Heart J. 2005;26(4):369-75; discussion 322-4. https://doi.org/10.1093/eurheartj/ehi114 PMid:15671045

47. Dariya B, Nagaraju GP. Understanding novel COVID-19: Its impact on organ failure and risk assessment for diabetic and cancer patients. Cytokine Growth Factor Rev. 2020;53:43-52. https://doi.org/10.1016/j.cytogfr.2020.05.001 PMid:32409230

48. Docherty AB, Harrison EM, Green CA, Hardwick HE, Pius R, Norman L, et al. Features of 20133 UK patients in hospital with COVID-19 using the ISARIC WHO clinical characterisation protocol: Prospective observational cohort study. BMJ. 
2020;369:m1985. https://doi.org/10.1136/bmj.m1985 PMid:32444460

49. Zhu N, Zhang D, Wang W, Li X, Yang B, Song J, et al. A Novel Coronavirus from Patients with Pneumonia in China, 2019. N Engl J Med. 2020;382(8):727-33. https://doi.org/10.1056/ NEJMoa2001017 PMid:31978945

50. Guan WJ, Liang WH, Zhao Y, Liang HR, Chen ZS, Li YM, et al. Comorbidity and its impact on 1590 patients with COVID-19 in China: A nationwide analysis. Eur Respir J. 2020;55(5):2000547. https://doi.org/10.1183/13993003.00547-2020 PMid:32217650

51. Xu G, Yang $Y, D u ~ Y$, Peng F, Hu P, Wang R, et al. Clinical pathway for early diagnosis of COVID-19: Updates from experience to evidence-based practice. Clin Rev Allergy Immunol. 2020;59(1):89-100. https://doi.org/10.1007/ s12016-020-08792-8

PMid:32328954

52. Javanmardi F, Keshavarzi A, Akbari A, Emami A, Pirbonyeh N. Prevalence of underlying diseases in died cases of COVID-19: A systematic review and meta-analysis. PLoS One. 2020;15(10):e0241265. https://doi.org/10.1371/journal. pone. 0241265

PMid:33095835

53. Hewitt R, Farne H, Ritchie A, Luke E, Johnston SL, Mallia P. The role of viral infections in exacerbations of chronic obstructive pulmonary disease and asthma. Ther Adv Respir Dis. 2016;10(2):158-74. https://doi.org/10.1177/1753465815618113 PMid:26611907

54. Liao H, Yang Z, Yang C, Tang Y, Liu S, Guan W, et al. Impact of viral infection on acute exacerbation of asthma in out-patient clinics: A prospective study. J Thorac Dis. 2016;8(3):505-12. https://doi.org/10.21037/jtd.2016.02.76 PMid:27076947

55. Halpin DM, Faner R, Sibila O, Badia JR, Agusti A. Do chronic respiratory diseases or their treatment affect the risk of SARSCoV-2 infection? Lancet Respir Med. 2020;8(5):436-8. https:// doi.org/10.1016/s2213-2600(20)30167-3

PMid:32251625

56. Richardson S, Hirsch JS, Narasimhan M, Crawford JM, McGinn T, Davidson K, et al. Presenting characteristics, comorbidities, and outcomes among 5700 patients hospitalized with COVID-19 in the New York city area. JAMA. 2020;323(20):2052-9. https://doi.org/10.1001/jama.2020.6775 PMid:32320003

57. Drake TM, Riad AM, Fairfield CJ, Egan C, Knight SR, Pius R, et al. Characterisation of in-hospital complications associated with COVID-19 using the ISARIC WHO clinical characterisation protocol UK: A prospective, multicentre cohort study. Lancet. 2021;398(10296):223-37. https://doi.org/10.1016/ s0140-6736(21)00799-6

\section{PMid:34274064}

58. Cariou B, Hadjadj S, Wargny M, Pichelin M, Al-Salameh A Allix I, et al. Phenotypic characteristics and prognosis of inpatients with COVID-19 and diabetes: The CORONADO study. Diabetologia. 2020;63(8):1500-15. https://doi.org/10.1007/ s00125-020-05180-x

PMid:32472191

59. Harmer D, Gilbert M, Borman R, Clark KL. Quantitative mRNA expression profiling of ACE 2, a novel homologue of angiotensin converting enzyme. FEBS Lett. 2002;532(1-2):107-10. https:// doi.org/10.1016/s0014-5793(02)03640-2

PMid:12459472

60. Beyerstedt S, Casaro EB, Rangel EB. COVID-19: Angiotensinconverting enzyme 2 (ACE2) expression and tissue susceptibility to SARS-CoV-2 infection. Eur J Clin Microbiol Infect Dis. 2021;40(5):905-19. https://doi.org/10.1007/ s10096-020-04138-6

\section{PMid:33389262}

61. Leung JM, Yang CX, Tam A, Shaipanich T, Hackett TL, Singhera GK, et al. ACE-2 expression in the small airway epithelia of smokers and COPD patients: Implications for COVID-19. Eur Respir J. 2020;55(5):2000688. https://doi. org/10.1183/13993003.00688-2020

PMid:32269089

62. Yuan P, Ai P, Liu Y, Ai Z, Wang Y, et al. Safety, tolerability, and immunogenicity of COVID-19 vaccines: A systematic review and meta-analysis. medRxiv. 2020;2020:20224998. https://doi. org/10.1101/2020.11.03.20224998

PMid:33173896

63. Banu N, Panikar SS, Leal LR, Leal AR. Protective role of ACE2 and its downregulation in SARS-CoV-2 infection leading to macrophage activation syndrome: Therapeutic implications. Life Sci. 2020;256:117905. https://doi.org/10.1016/j.lfs.2020.117905 PMid:32504757

64. Diao B, Wang C, Tan Y, Chen X, Liu Y, Ning L, et al. Reduction and functional exhaustion of $\mathrm{T}$ cells in patients with Coronavirus disease 2019 (COVID-19). Front Immunol. 2020;11:827. https:// doi.org/10.3389/fimmu.2020.00827 PMid:32425950

65. Wang Z, Yang B, Li Q, Wen L, Zhang R. Clinical features of 69 cases with coronavirus disease 2019 in Wuhan, China. Clin Infect Dis. 2020;71(15):769-77. https://doi.org/10.1093/cid/ ciaa272

PMid:32176772

66. Manthei DM, Schwantes EA, Mathur SK, Guadarrama AG Kelly EA, Kelly JE, et al. Nasal lavage VEGF and TNF-alpha levels during a natural cold predict asthma exacerbations. Clin Exp Allergy. 2014;44(12):1484-93. https://doi.org/10.1111/ cea. 12387

PMid:25109477

67. Kubysheva N, Boldina M, Eliseeva T, Soodaeva S, Klimanov I, Khaletskaya $A$, et al. Relationship of serum levels of IL-17, IL-18, TNF-alpha, and lung function parameters in patients with COPD, asthma-COPD overlap, and bronchial asthma. Mediators Inflamm. 2020;2020:4652898. https://doi. org/10.1155/2020/4652898

\section{PMid:32733164}

68. Huang $A X$, Lu LW, Liu WJ, Huang M. Plasma inflammatory cytokine IL-4, IL-8, IL-10, and TNF-alpha levels correlate with pulmonary function in patients with Asthma-chronic obstructive pulmonary disease (COPD) overlap syndrome. Med Sci Monit. 2016;22:2800-8. https://doi.org/10.12659/msm.896458 PMid:27501772

69. Garth J, Barnes JW, Krick S. Targeting cytokines as evolving treatment strategies in chronic inflammatory airway diseases. Int J Mol Sci. 2018;19(11):3402. https://doi.org/10.3390/ ijms 19113402

PMid:30380761

70. Celli BR, Locantore N, Yates J, Tal-Singer R, Miller BE, Bakke P, et al. Inflammatory biomarkers improve clinical prediction of mortality in chronic obstructive pulmonary disease. Am J Respir Crit Care Med. 2012;185:1065-72. https://doi.org/10.1164/ rccm.201110-1792OC PMid:22427534

71. Ridker PM. From C-reactive protein to interleukin-6 to interleukin-1: Moving upstream to identify novel targets for atheroprotection. Circ Res. 2016;118(1):145-56. https://doi. org/10.1161/CIRCRESAHA.115.306656

PMid:26837745 
72. Donaldson GC, Seemungal TA, Patel IS, Bhowmik A, Wilkinson TM, Hurst JR, et al. Airway and systemic inflammation and decline in lung function in patients with COPD. Chest. 2005;128:1995-2004. https://doi.org/10.1378/chest.128.4.1995 PMid: 16236847

73. Fermont JM, Masconi KL, Jensen MT, Ferrari R, Di Lorenzo VA, Marott JM, et al. Biomarkers and clinical outcomes in COPD: A systematic review and meta-analysis. Thorax. 2019;74(5):439-46. https://doi.org/10.1136/ thoraxjnl-2018-211855

PMid:30617161

74. Shi H, Han X, Jiang N, Cao Y, Alwalid O, Gu J, et al. Radiological findings from 81 patients with COVID-19 pneumonia in Wuhan, China: A descriptive study. Lancet Infect Dis. 2020;20:425-34. https://doi.org/10.1016/s1473-3099(20)30086-4 PMid:32105637

75. Andreassen SL, Liaaen ED, Stenfors N, Henriksen AH. Impact of pneumonia on hospitalizations due to acute exacerbations of COPD. Clin Respir J. 2014;8(1):93-9. https://doi.org/10.1111/ crj. 12043

PMid:23889911

76. Trethewey SP, Hurst JR, Turner AM. Pneumonia in exacerbations of COPD: What is the clinical significance? ERJ Open Res. 2020;6(1):282-2019. https://doi. org/10.1183/23120541.00282-2019

PMid:32010721

77. Tal-Singer R, Crapo JD. COPD at the time of COVID-19: A COPD foundation perspective. Chronic Obstr Pulm Dis. 2020;7(2):73-5. https://doi.org/10.15326/jcopdf.7.2.2020.0149 PMid:32324976

78. Fang $\mathrm{Y}$, Zhang $\mathrm{H}, \mathrm{Xie} \mathrm{J}$, Lin M, Ying L, Pang P, et al. Sensitivity of Chest CT for COVID-19: Comparison to RT-PCR. Radiology. 2020;296(2):E115-7. https://doi.org/10.1148/radiol.2020200432 PMid:32073353

79. Yue $\mathrm{H}$, Zhang $\mathrm{M}$, Xing L, Wang $\mathrm{K}$, Rao $\mathrm{X}$, Liu $\mathrm{H}$, et al. The epidemiology and clinical characteristics of co-infection of SARS-CoV-2 and influenza viruses in patients during COVID-19 outbreak. J Med Virol. 2020;92(11):2870-3. https:// doi.org/10.1002/jmv.26163

PMid:32530499

80. Gousseff M, Penot P, Gallay L, Batisse D, Benech N, Bouiller K, et al. Clinical recurrences of COVID-19 symptoms after recovery: Viral relapse, reinfection or inflammatory rebound? J Infect. 2020;81(5):816-46. https://doi.org/10.1016/j.jinf.2020.06.073 PMid:32619697

81. Wong HY, Lam HY, Fong AH, Leung ST, Chin TW, Lo CS, et al. Frequency and distribution of chest radiographic findings in patients positive for COVID-19. Radiology. 2020;296(2):E72-8. https://doi.org/10.1148/radiol.2020201160

PMid:32216717

82. Rodriguez-Morales

AJ, Cardona-Ospina $\mathrm{JA}$, Gutierrez-Ocampo E, Villamizar-Pena R, Holguin-Rivera Y, Escalera-Antezana JP, et al. Clinical, laboratory and imaging features of COVID-19: A systematic review and meta-analysis. Travel Med Infect Dis. 2020;34:101623. https://doi.org/10.1016/j. tmaid.2020.101623

PMid:32179124

83. Inui $S$, Fujikawa A, Jitsu M, Kunishima N, Watanabe $S$, Suzuki $Y$, et al. Chest CT findings in cases from the cruise ship diamond princess with Coronavirus disease (COVID-19). Radiol Cardiothorac Imaging. 2020;2(2):e200110. https://doi. org/10.1148/ryct.2020200110

PMid:33778566

84. Wu F, Zhou Y, Wang Z, Xie M, Shi Z, Tang Z, et al. Clinical characteristics of COVID-19 infection in chronic obstructive pulmonary disease: A multicenter, retrospective, observational study. J Thorac Dis. 2020;12(5):1811-23. https://doi. org/10.21037/jtd-20-1914

PMid:32642086

85. Kulkarni S, Down B, Jha S. Point-of-care lung ultrasound in intensive care during the COVID-19 pandemic. Clin Radiol. 2020;75(9):710.e711-4. https://doi.org/10.1016/j. crad.2020.05.001

PMid:32405081

86. Saminan S, Julisafrida L, Sakdiah S, Idayati R, Fajri N, Iqhrammullah M. Nanoparticles-based face masks and respirators for preventing COVID-19 transmission: Breathability versus biocidal activities. Indian J Forensic Med Toxicol. 2021;15:4107-16. https://doi.org/10.37506/ijfmt.v15i2.15018

87. McAuley H, Hadley K, Elneima O, Brightling CE, Evans RA, Steiner MC, et al. COPD in the time of COVID-19: An analysis of acute exacerbations and reported behavioural changes in patients with COPD. ERJ Open Res. 2021;7(1):718-2020. https://doi.org/10.1183/23120541.00718-2020 PMid:33527075

88. Wahidi MM, Lamb C, Murgu S, Musani A, Shojaee S, Sachdeva A, et al. American association for bronchology and interventional pulmonology (AABIP) statement on the use of bronchoscopy and respiratory specimen collection in patients with suspected or confirmed COVID-19 infection. J Bronchology Interv Pulmonol. 2020;27(4):e52-4. https://doi.org/10.1097/ LBR.0000000000000681

PMid:32195687

89. Aggarwal AN, Gupta D, Jindal SK. The relationship between FEV1 and peak expiratory flow in patients with airways obstruction is poor. Chest. 2006;130(5):1454-61. https://doi. org/10.1378/chest.130.5.1454

PMid:17099024

90. Hernandez CR, Fernandez MN, Sanmartin AP, Roibas CM, Dominguez LC, Rial MI, et al. Validation of the portable airsmart spirometer. PLoS One. 2018;13(2):e0192789. https://doi. org/10.1371/journal.pone.0192789

PMid:29474502

91. Reis AJ, Alves C, Furtado S, Ferreira J, Drummond M, RobaloCordeiro $\mathrm{C}$, et al. COPD exacerbations: Management and hospital discharge. Pulmonology. 2018;24(6):345-50. https:// doi.org/10.1016/j.pulmoe.2018.06.006

PMid:30049647

92. Montserrat-Capdevila J, Godoy P, Marsal JR, Barbe F. Predictive model of hospital admission for COPD exacerbation. Respir Care. 2015;60(9):1288-94. https://doi.org/10.4187/ respcare. 04005

PMid:26286737

93. Hirano $T$, Matsunaga $K$, Hamada $K$, Uehara $S$, Suetake $R$, Yamaji $Y$, et al. Combination of assist use of short-acting beta-2 agonists inhalation and guidance based on patient-specific restrictions in daily behavior: Impact on physical activity of Japanese patients with chronic obstructive pulmonary disease. Respir Investig. 2019;57(2):133-9. https://doi.org/10.1016/j. resinv.2018.12.001

PMid:30612948

94. Criner GJ, Bourbeau J, Diekemper RL, Ouellette DR, Goodridge D, Hernandez D, et al. Executive summary: Prevention of acute exacerbation of COPD: American college of chest physicians and canadian thoracic society guideline. Chest. 2015;147(4):883-93. https://doi.org/10.1378/chest.14-1677 PMid:25320966

95. Miravitlles $M$, Auladell-Rispau A, Monteagudo $M$, Vazquez-Niebla JC, Mohammed J, Nuñez A, et al. Systematic review on long-term adverse effects of inhaled corticosteroids in the treatment of COPD. Eur Respir Rev. 2021;30(160):210075. 
https://doi.org/10.1183/16000617.0075-2021 PMid:34168063

96. Wu L, Lan N, Yang X. Effects of empirical glucocorticoid use on severe acute exacerbation of COPD during hospitalization. Int J Chron Obstruct Pulmon Dis. 2021;16:2419-31. https://doi. org/10.2147/COPD.S300789

PMid:34471349

97. de Jong YP, Uil SM, Grotjohan HP, Postma DS, Kerstjens HA, Van Den Berg JW, et al. Oral or IV prednisolone in the treatment of COPD exacerbations: A randomized, controlled, doubleblind study. Chest. 2007;132(6):1741-7. https://doi.org/10.1378/ chest.07-0208

PMid: 17646228

98. Hasan SS, Capstick T, Zaidi ST, Kow CS, Merchant HA Use of corticosteroids in asthma and COPD patients with or without COVID-19. Respir Med. 2020;170:106045. https://doi. org/10.1016/j.rmed.2020.106045

PMid:32843175

99. Kaiser UB, Mirmira RG, Stewart PM. Our response to COVID-19 as endocrinologists and diabetologists. J Clin Endocrinol Metab. 2020;105(5):1299-301. https://doi.org/10.1210/clinem/dgaa148 PMid:32232480

100. Wu C, Chen X, Cai Y, Xia J, Zhou X, Xu S, et al. Risk factors associated with acute respiratory distress syndrome and death in patients with Coronavirus disease 2019 Pneumonia in Wuhan, China. JAMA Intern Med. 2020;180(7):934-43. https:// doi.org/10.1001/jamainternmed.2020.0994 PMid:32167524

101. Wang $Y$, Zhang $Y$, Xie W, Yan B, Liu F, Zhang $Y$, et al. Mesenchymal stem cell-derived exosomes inhibits the activation of NLRP3 inflammasome in mice after myocardial infarction by releasing circASXL1. J Mol Cell Cardiol. 2020;140:57. https:// doi.org/10.1016/j.yjmcc.2019.11.137

102. Schultze A, Walker AJ, MacKenna B, Morton CE, Bhaskaran $K$, Brown JP, et al. Risk of COVID-19-related death among patients with chronic obstructive pulmonary disease or asthma prescribed inhaled corticosteroids: An observational cohort study using the OpenSAFELY platform. Lancet Respir Med. 2020;8(11):1106-20. https://doi.org/10.1016/s2213-2600(20)30415-x PMid:32979987

103. Jacobs DM, Pandit U, Sethi S. Acute exacerbations in chronic obstructive pulmonary disease: Should we use antibiotics and if so, which ones? Curr Opin Infect Dis. 2019;32(2):143-51. https://doi.org/10.1097/QCO.0000000000000533 PMid:30672788

104. Verroken A, Scohy A, Gerard L, Wittebole X, Collienne C, Laterre RF, et al. Co-infections in COVID-19 critically ill and antibiotic management: A prospective cohort analysis. Crit Care. 2020;24(1):410. https://doi.org/10.1186/ s13054-020-03135-7

\section{PMid:32646494}

105. Rawson TM, Moore LSP, Zhu N, Ranganathan N, Skolimowska K, Gilchrist $\mathrm{M}$, et al. Bacterial and fungal coinfection in individuals with coronavirus: A rapid review to support COVID-19 antimicrobial prescribing. Clin Infect Dis. 2020;71(9):2459-68. https://doi.org/10.1093/cid/ciaa530

PMid:32358954

106. COVID-19 Clinical Management: Living Guidance; 2021. Available from: https://www.who.int/publications/i/item/WHO2019-nCoV-clinical-2021-1 [Last accessed on 2021 Nov 08].

107. Sadowska AM, Verbraecken J, Darquennes K, De Backer WA. Role of $\mathrm{N}$-acetylcysteine in the management of COPD. Int $J$ Chron Obstruct Pulmon Dis. 2006;1()4:425-34. https://doi. org/10.2147/copd.2006.1.4.425 PMid: 18044098

108. Shaykhiev R. Emerging biology of persistent mucous cell hyperplasia in COPD. Thorax. 2019;74(1):4-6. https://doi. org/10.1136/thoraxjnl-2018-212271

\section{PMid:30266881}

109. Crespo-Lessmann A, Bernal S, Del Rio E, Rojas E, MartinezRivera C, Marina N, et al. Association of the CFTR gene with asthma and airway mucus hypersecretion. PLoS One. 2021;16(6):e0251881. https://doi.org/10.1371/journal. pone. 0251881

PMid:34086689

110. Tenorio M, Graciliano NG, Moura FA, Oliveira ACM, Goulart MO. N-acetylcysteine (NAC): Impacts on human health. Antioxidants (Basel). 2021;10(6):967. https://doi.org/10.3390/ antiox10060967

PMid:34208683

111. Cazzola M, Calzetta L, Page C, Jardim J, Chuchalin AG Rogliani $\mathrm{P}$, et al. Influence of $\mathrm{N}$-acetylcysteine on chronic bronchitis or COPD exacerbations: A meta-analysis. Eur Respir Rev. 2015;24(137):451-61. https://doi. org/10.1183/16000617.00002215 PMid:26324807

112. Sadowska AM, Manuel YK, de Backer WA. Antioxidant and antiinflammatory efficacy of NAC in the treatment of COPD: Discordant in vitro and in vivo dose-effects: A review. Pulm Pharmacol Ther. 2007;20(1):9-22. https://doi.org/10.1016/j.pupt.2005.12.007 PMid: 16458553

113. de Flora S, Balansky R, La Maestra S. Rationale for the use of $\mathrm{N}$-acetylcysteine in both prevention and adjuvant therapy of COVID-19. FASEB J. 2020;34(10):13185-93. https://doi. org/10.1096/fj.202001807 PMid:32780893

114. Poe FL, Corn J. N-acetylcysteine: A potential therapeutic agent for SARS-CoV-2. Med Hypotheses. 2020;143:109862. https:// doi.org/10.1016/j.mehy.2020.109862 PMid:32504923 